\title{
Oxide Stability Diagram of Liquid Steels - Construction and Utilization
}

\author{
Youn-Bae KANG ${ }^{1,2) *}$ and Sung-Hoon JUNG ${ }^{3)}$ \\ 1) Graduate Institute of Ferrous Technology, Pohang University of Science and Technology, 77 Cheongamro, Namgu, Pohang, \\ Kyungbuk, 37673 Rep. of Korea. $\quad 2)$ CRCT, Department of Chemical Engineering, École Polytechnique de Montréal, \\ Montreal, OC, H3C 3A7, Canada. $\quad 3)$ Kwangyang Process Research Group, Technical Research Laboratories, POSCO, \\ Kwangyang, Jeonnam, 57807 Rep. of Korea.
}

(Received on March 20, 2018; accepted on April 16, 2018)

\begin{abstract}
Oxide stability diagrams are often used to figure out types of oxide inclusions (i.e., phase) in liquid steels. Such diagram is useful for quick identification of the inclusions by concentrations of deoxidizing components. Obviously, deoxidation of the liquid steel to form the inclusions takes place rapidly. Therefore, thermodynamic principles are applied in the construction of the diagram. To construct it in the correct manner, and to use it in more versatile manner, available methods were reviewed, and possible limits are discussed. It is pointed out that an oxide stability diagram is a projection of several iso-oxygen phase diagram sections, each of which should obey the phase diagram rule and should represent accurate thermodynamic equilibria. In this regard, a CALPHAD method is preferred to conventionally used methods that 1) stable oxide phases are naturally taken into account, 2) activity of oxide component even in solution phase (e.g., liquid oxide) is not assumed to be a constant, and 3) iso-oxygen contours are calculated efficiently as Zero-Phase Fraction (ZPF) line of several oxide phases, which are in equilibrium with the liquid steel. Rule of the phase diagram construction is automatically obeyed in the CALPHAD method. Interpretation and utilization of the oxide stability diagram are discussed. It is proposed that concentration axes be extended to a lower concentration where liquid oxide (rich in Fe oxide) forms. It is also explained how oxide stability diagram can be used to read deoxidation/reoxidation path of liquid steels. Finally, consideration of $\mathrm{C}$ in a liquid steel is emphasized.
\end{abstract}

KEY WORDS: stability diagram; liquid steel; thermodynamics; reoxidation; CO(g); CALPHAD.

\section{Introduction}

Stability diagrams of oxide phase relevant to liquid steel deoxidation have been used in steelmaking and refining researches. Prediction of inclusion phases in equilibrium with a liquid steel is a primary interest. Typically, a stability diagram is drawn on a rectangular coordinate with two axes of concentrations of oxidizing components (e.g., logarithm scale of mass pct.) at a given temperature. Depending on the number of components in the steel, compositions of some components are either set to constants respectively or set to be dependent each other. A number of iso-[ppm O] lines are often shown, and phase boundaries separating two different oxide phase regions are superimposed. Finally, labels of the stable oxide phases are added, which allows quick identification of the stable inclusions by the steel composition. As the compositions of two oxidizing components are used as the axes variables, this type of diagram is often used to figure out inclusion phases in liquid steel, which was simultaneously deoxidized by the two components. Most well-known diagrams in literature are due to $\mathrm{Si}-\mathrm{Mn}$ deoxi-

\footnotetext{
* Corresponding author: E-mail: ybkang@postech.ac.kr DOI: http://dx.doi.org/10.2355/isijinternational.ISIJINT-2018-198
}

dation, ${ }^{1)} \mathrm{Si}-\mathrm{Al}$ deoxidation, ${ }^{2-4)} \mathrm{Mg}-\mathrm{Al}$ deoxidation, ${ }^{5-13)}$ Al-Ca deoxidation, ${ }^{11,14-16)} \mathrm{Ti}-\mathrm{Al}$ deoxidation, ${ }^{16-23)}$ etc. A partial list of such diagrams published in literature is shown in Table 1. ${ }^{1-36)}$

One of typical examples is shown in Fig. 1. This figure shows the equilibrium relations for deoxidation of steel with $\mathrm{Mn}$ and $\mathrm{Si}$ at various temperatures. ${ }^{1)}$ It is determined by a reaction:

$$
\begin{gathered}
2 \underline{\mathrm{Mn}}+\left(\mathrm{SiO}_{2}\right)=\underline{\mathrm{Si}}+2(\mathrm{MnO}) ; \quad K_{[1 \mathrm{a}]} \ldots \ldots \ldots . . . \\
\log K_{[1 \mathrm{a}]}=2 \log a_{\mathrm{MnO}}+\log a_{\underline{\mathrm{Si}}}-2 \log a_{\underline{\mathrm{Mn}}}-\log a_{\mathrm{SiO}_{2}} \ldots
\end{gathered}
$$

where $\underline{M}(M=\mathrm{Mn}, \mathrm{Si})$ refers to the deoxidizing component dissolved in the liquid steel, with respect to $1 \mathrm{wt} \%$ standard state, and $\left(M \mathrm{O}_{x}\right)$ refers to the oxide dissolve in the molten manganese silicate, with respect to pure solid standard state. For the sake simplicity, it may be assumed $a_{\underline{\mathrm{M}}} \cong$ [pct M] for an infinitely dilute solution. When the liquid steel is in equilibrium with "solid silica" and "molten manganese silicate" simultaneously, $a_{\mathrm{SiO}_{2}}=1$ and $a_{\mathrm{MnO}}$ is a constant at the temperature. The Eq. (1b) becomes:

$$
\log [\mathrm{pctSi}]=2 \log [\mathrm{pct} \mathrm{Mn}]+\left(\log K_{[1 \mathrm{a}]}-2 \log a_{\mathrm{MnO}}\right) \ldots
$$

where the terms in the parenthesis held constant. This yields 
ISIJ International, Vol. 58 (2018), No. 8

Table 1. Previously reported oxide stability diagrams of various steel systems. Method for the construction of each diagram was identified as: 1) "Border line" if no iso-oxygen contours were given, 2) "Iso-oxygen contours" if iso-oxygen contours were obtained by method described in Sec. 2.2, and 3) "CALPHAD" if Gibbs energy minimization was employed.

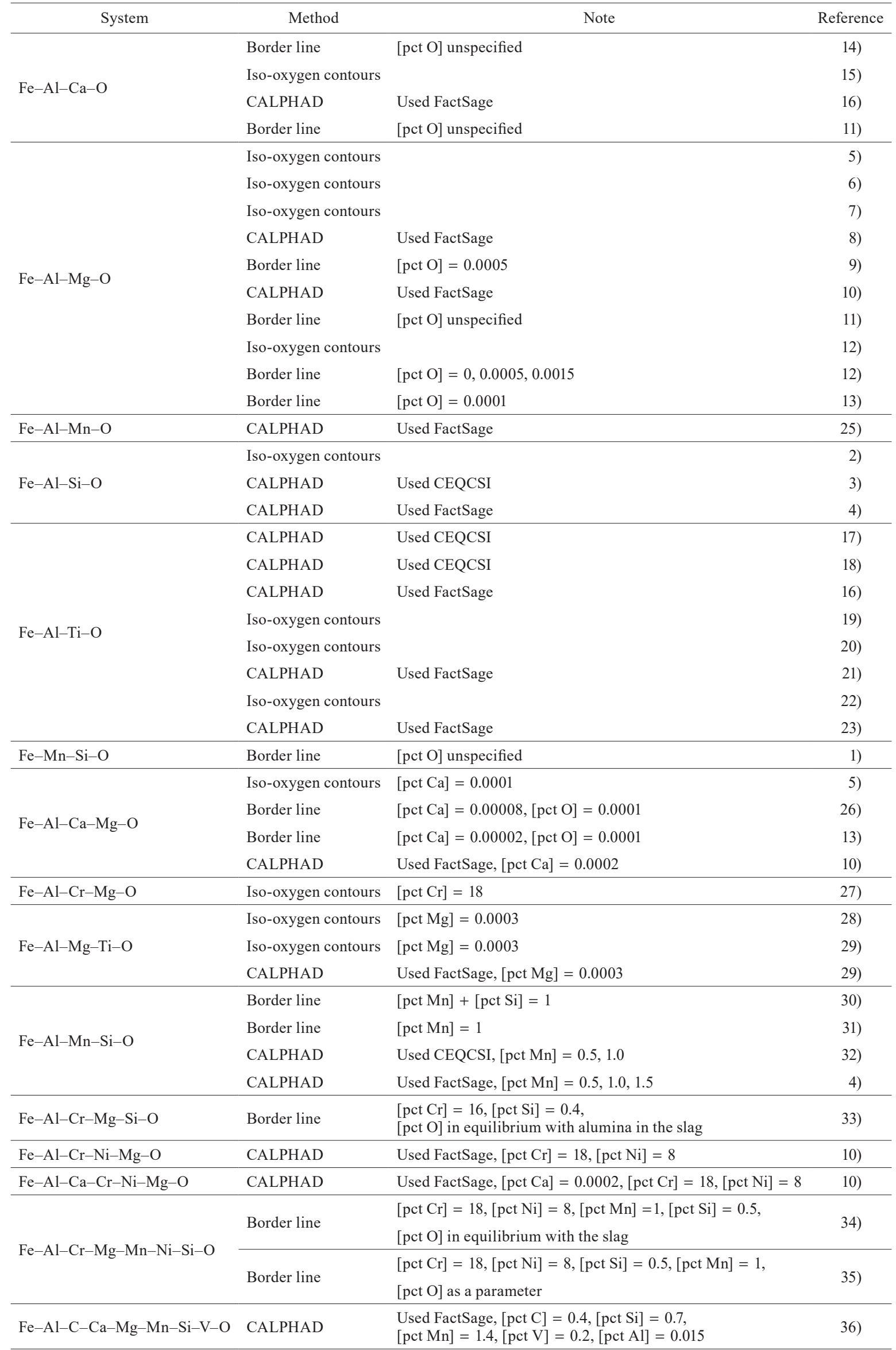




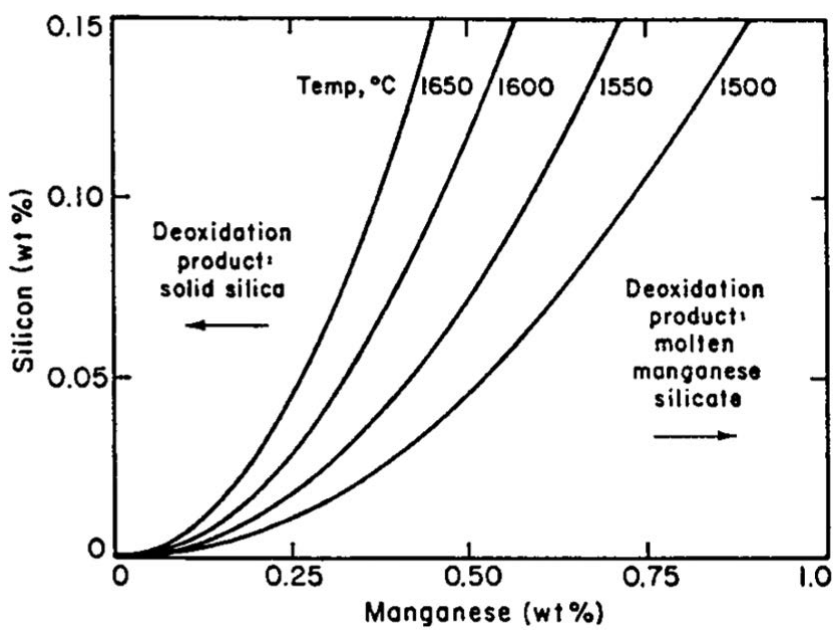

Fig. 1. Equilibrium relations for deoxidation of steel with $\mathrm{Mn}$ and Si at $1600^{\circ} \mathrm{C}^{1)}$

the following relation:

$$
[\mathrm{pct} \mathrm{Si}]=\left(\frac{K_{[\mathrm{la}]}}{a_{\mathrm{MnO}}^{2}}\right)[\mathrm{pct} \mathrm{Mn}]^{2}
$$

and corresponds to one of curves in the Fig. 1. When the activity coefficients of $\mathrm{Si}$ and $\mathrm{Mn}$ are rigorously considered, the Eq. (1c) is then slightly modified. The Fig. 1 gives an information that the stable oxide in the liquid steel is "solid silica" if [pct Si] is higher than $\left(\frac{K_{[1 \mathrm{a}]}}{a_{\mathrm{MnO}}^{2}}\right)[\mathrm{pct} \mathrm{Mn}]^{2}$ at a given [pct $\mathrm{Mn}$ ]. If [pct $\mathrm{Si}$ ] is lower than that, then the stable oxide is molten "manganese silicate". If [pct Si] and [pct $\mathrm{Mn}$ ] satisfies the Eq. (1c), then both the solid silica and the molten manganese silicate co-exist with the liquid steel. This information is useful if one wants to know what type of inclusion forms in the liquid steel with given [pct $\mathrm{Si}$ ] and [pct Mn]. In this figure, however, oxygen concentration in the liquid steel is not explicitly shown.

The other example is shown in Fig. 2. This figure shows the equilibrium relations for deoxidation of steel with $\mathrm{Al}$ and $\mathrm{Ca}$ at $\left.1600^{\circ} \mathrm{C}^{15}\right)$ Various oxides $(\mathrm{CaO}$, liquid oxide, $\mathrm{CA}$, $\mathrm{CA}_{2}, \mathrm{CA}_{6}$, and $\mathrm{Al}_{2} \mathrm{O}_{3}$, where $\mathrm{C}$ and $\mathrm{A}$ stand for $\mathrm{CaO}$ and $\mathrm{Al}_{2} \mathrm{O}_{3}$, respectively) are stable depending on concentrations of $\mathrm{Al}$ and $\mathrm{Ca}$. Thick lines represent concentration of $\mathrm{Ca}$ and Al where two oxides out of the above oxide family are in equilibrium with the liquid steel. For example, a thick line separating "CA" and " $\mathrm{CA}_{2}$ " can be obtained by the following reaction:

$$
2 \underline{\mathrm{Al}}+7 \mathrm{CaAl}_{2} \mathrm{O}_{4}(\mathrm{~s})=3 \underline{\mathrm{Ca}}+4 \mathrm{CaAl}_{4} \mathrm{O}_{7}(\mathrm{~s}) ; \quad K_{[2 \mathrm{a}]} \ldots
$$

$\log K_{[2 \mathrm{a}]}=4 \log a_{\mathrm{CaAl}_{4} \mathrm{O}_{7}}+3 \log a_{\underline{\mathrm{Ca}}}-2 \log a_{\underline{\mathrm{Al}}}-7 \log a_{\mathrm{CaAl}_{2} \mathrm{O}_{4}}$

where activities of "CA" and " $\mathrm{CA}_{2}$ " with respect to pure solids may be set to unity, unless these exhibit noticeable non-stoichiometry or solubility of other component.

Contrary to the Fig. 1, a number of thin lines are also shown. These are iso-oxygen contours that represent equilibrium oxygen concentration in the liquid steel when the steel is in equilibrium with a designated oxide phase. According to a series of the iso-oxygen contours, it is seen

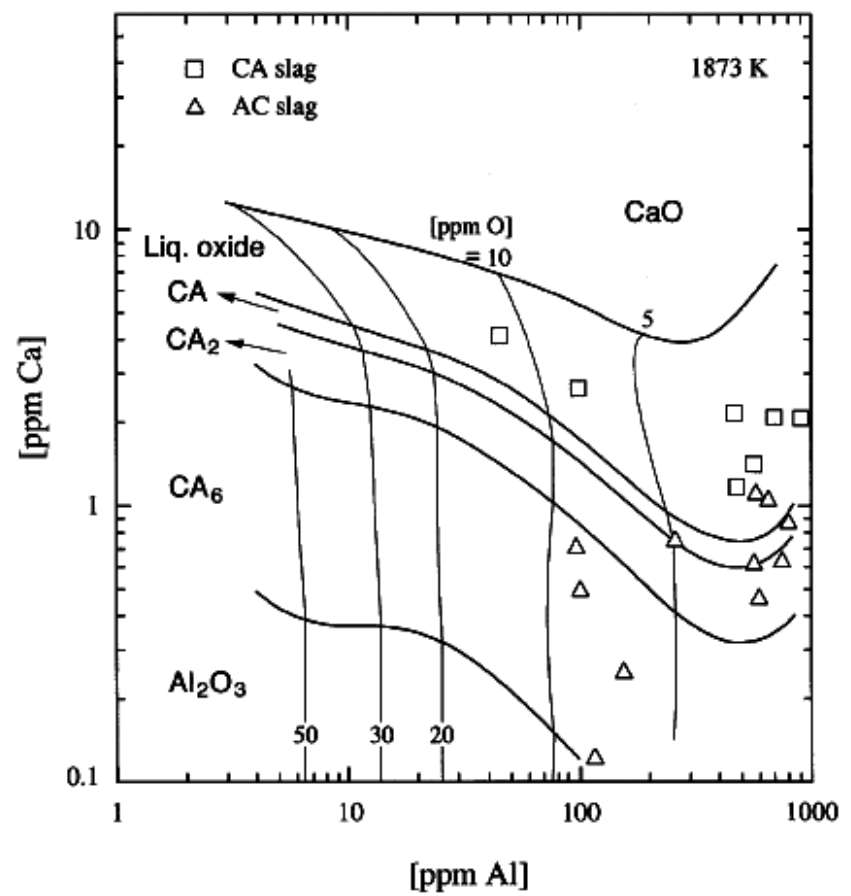

Fig. 2. Phase stability region of the $\mathrm{Fe}-\mathrm{Al}-\mathrm{Ca}-\mathrm{O}$ system at $1600^{\circ} \mathrm{C} .{ }^{15)}$ " $\mathrm{C}$ " and " $\mathrm{A}$ " stand for $\mathrm{CaO}$ and $\mathrm{Al}_{2} \mathrm{O}_{3}$, respectively.

that the oxygen concentration varies on the thick lines separating two oxide regions. Such information is not seen in the Fig. 1. Various versions of this diagram have been reported elsewhere. ${ }^{11,14-16)}$ Some of those did not show iso-oxygen contours. ${ }^{11,14)}$ This is obviously less informative to the one with iso-oxygen contours.

Although it is of practical use and important in steelmaking and refining researches, its construction and interpretation are less clear and sometimes in error. As is noted in Table 1, some of previously reported stability diagrams did not properly treat oxygen concentration in the diagram. The oxygen concentration was either not specified, or set to a constant, or treated as parameters. This is certainly in error. This seems partly because one neglects that the oxide stability diagram is, in fact, a projection of several phase diagram sections. Any true phase diagram section should obey phase diagram rule. ${ }^{3738)}$ Each point on the diagram section represents one unique equilibrium state. Although this does not apply directly to phase diagram projections such as the oxide stability diagram, it consists of several diagram sections projected onto a common plane. ${ }^{37)}$

The other point often neglected is ignorance of possible phase and component. As will be described in Sec. 2, an oxide stability diagram was often constructed assuming existence of the particular phase in equilibrium with the liquid steel. If the assumed phase is indeed not stable, or a different phase that should have been stable is not taken into account, the resultant diagram is certainly in error. One of such cases is due to oxide stability diagram of the $\mathrm{Fe}-\mathrm{Al}-\mathrm{Ti}-\mathrm{O}$ system, which is relevant to Ti added Ultra Low C (ULC) steel grade. Figure 3 shows an oxide stability diagram of the $\mathrm{Fe}-\mathrm{Al}-\mathrm{Ti}-\mathrm{O}$ system by Kang and Lee. ${ }^{23)}$ " $\mathrm{Al}_{2} \mathrm{O}_{3}$ ", " $\mathrm{FeAl}_{2} \mathrm{O}_{4}$ ", "( $\left.\mathrm{Ti}, \mathrm{Fe}\right)_{3} \mathrm{O}_{5}$ ", " $\left(\mathrm{Ti}, \mathrm{Al}_{2}\right)_{2} \mathrm{O}_{3}$ ", and "liquid oxide" are seen as stable oxide phases. This diagram should be reduced to deoxidation equilibria of single component 


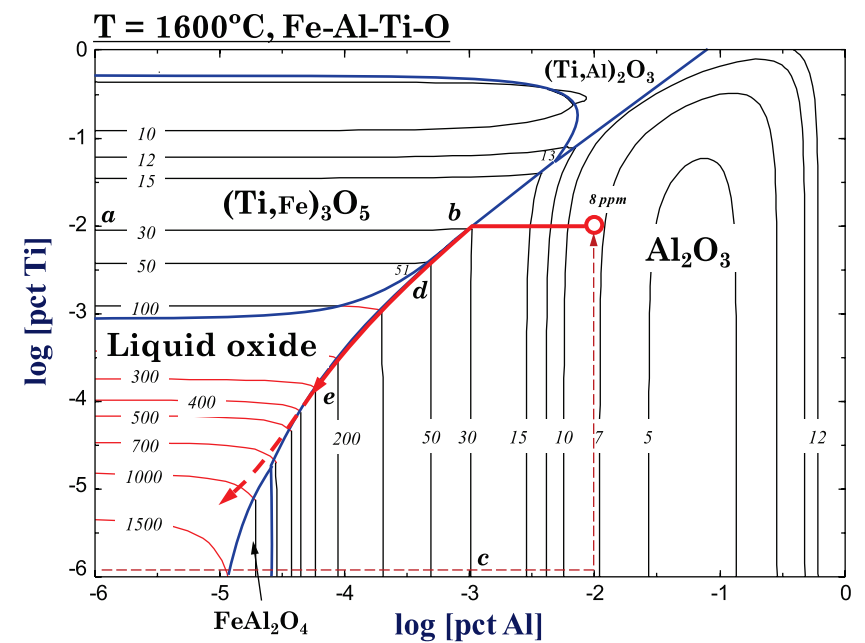

Fig. 3. Oxide stability diagram of the $\mathrm{Fe}-\mathrm{Al}-\mathrm{Ti}-\mathrm{O}$ system at $1600^{\circ} \mathrm{C}$. Numbers on each thin lines are [ppm O] in liquid steel. Stable oxide phases in equilibrium with liquid steel are labeled: $\mathrm{Al}_{2} \mathrm{O}_{3}$ - corundum, $(\mathrm{Ti}, \mathrm{Al})_{2} \mathrm{O}_{3}$ - ilmenite solid solution with dilute $\mathrm{Al}_{2} \mathrm{O}_{3},(\mathrm{Ti}, \mathrm{Fe})_{3} \mathrm{O}_{5}$ - pseudobrookite solid solution with dilute $\mathrm{FeTi}_{2} \mathrm{O}_{5}$, Liquid oxide - liquid composed of $\mathrm{Fe}_{t} \mathrm{O}-\mathrm{Al}_{2} \mathrm{O}_{3}-\mathrm{TiO}_{x}$. (Online version in color.)

deoxidizer ( $\mathrm{Al}$ or $\mathrm{Ti}$ ) when concentration of either $\mathrm{Al}$ or $\mathrm{Ti}$ is very low. Figures $\mathbf{4}$ and $\mathbf{5}$ show deoxidation equilibria of the $\mathrm{Fe}-\mathrm{Al}-\mathrm{O}$ system and the $\mathrm{Fe}-\mathrm{Ti}-\mathrm{O}$ system, respectively. Equilibrium oxide phase, equilibrium concentrations of $\mathrm{O}$ and $\mathrm{Al}$ (or $\mathrm{Ti}$ ) are all consistent with the information shown in $x$-axis (or $y$-axis) of the Fig. 3. Some of previously reported stability diagrams were not consistent with the deoxidation equilibria of even single component deoxidizer. This is due to ignorance of possible stable phase or incorrect assumption of oxide phase during the construction of the stability diagram.

Many grades of steel contain $\mathrm{C}$ but its presence is also often neglected. $\mathrm{C}$ exhibits strong affinity to $\mathrm{O}$, thus altering thermodynamic state of the $\mathrm{O}$ : $\mathrm{C}$ decreases the activity coefficient of $\mathrm{O}$, and even results in formation of $\mathrm{CO}(\mathrm{g})$. This should also be taken into account when a steel contains $\mathrm{C}$.

The purpose of this article is to explain how oxide stability diagram would be most appropriately constructed and used. In particular, the use of CALPHAD method is introduced, ${ }^{39)}$ and its usefulness in constructing oxide stability diagrams is discussed. In the CALPHAD method, several iso-oxygen phase diagram sections are calculated. Necessary parts of the calculated sections are then merged in one diagram that consists of the oxide stability diagram. During the calculation, rule of phase diagram construction is obeyed. Carefully assessed thermodynamic database for the liquid steel and relevant oxide phases are used during the calculation. In addition to the use of the CALPHAD method, right interpretation and possible use of oxide stability diagram are discussed.

Throughout this article, concentration of various components in liquid steels is used. Unless other is stated, it means soluble (or dissolved) concentration, and is written as [pct $i]$ to refer mass percent of $i$ or [ppm $i]$ to refer mass part per million of $i$. Also, a thin line representing composition of the steel of a given oxygen concentration is called an "iso-oxygen contour". A thick line separating stable oxide

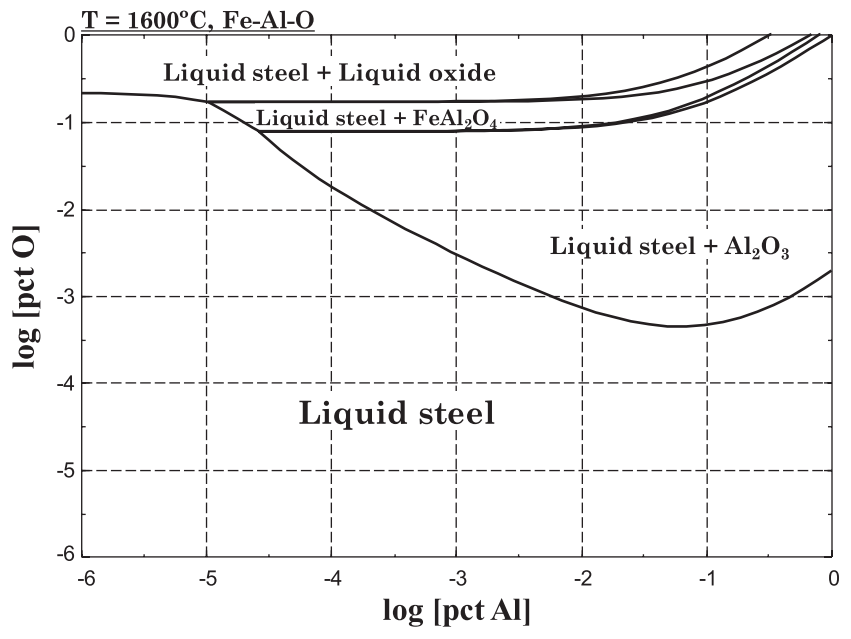

Fig. 4. A deoxidation curve of the $\mathrm{Fe}-\mathrm{Al}-\mathrm{O}$ system at $1600^{\circ} \mathrm{C}$. Liquid oxide is in equilibrium with liquid steel when [pct Al] $<1.0471 \times 10^{-05}$.

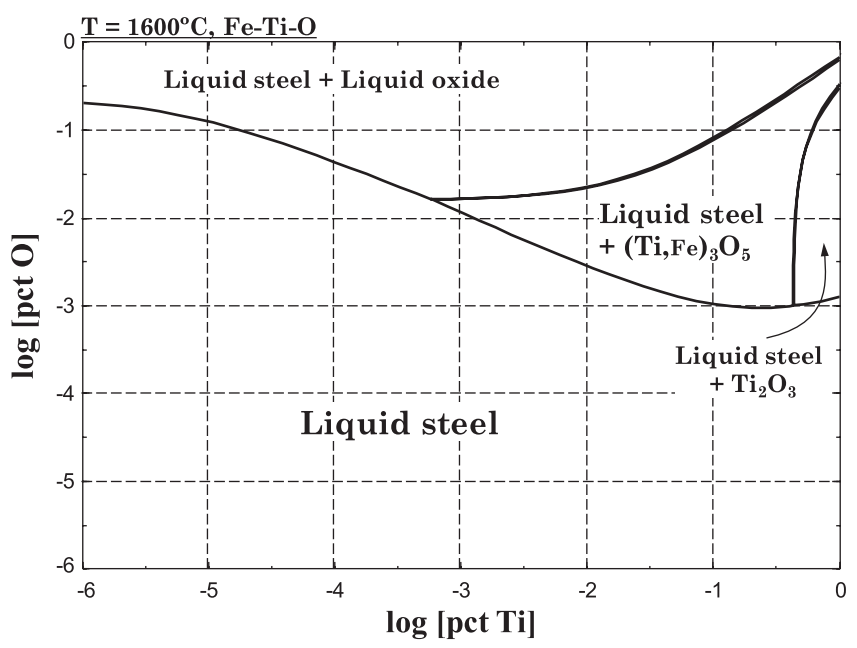

Fig. 5. A deoxidation curve of the $\mathrm{Fe}-\mathrm{Ti}-\mathrm{O}$ system at $1600^{\circ} \mathrm{C}$. Liquid oxide is in equilibrium with liquid steel when [pct $\mathrm{Ti}]<8.2533 \times 10^{-04}$.

regions is called as a "phase boundary".

\section{General Calculation Procedure of An Oxide Stability Diagram}

In this section, it is introduced how this type of diagram is constructed, with the Fig. 3 as an example. A recent article by Zhang et al. ${ }^{12)}$ categorized methods of constructing oxide stability diagrams in two ways: iso-oxygen contours method and border lines method. In addition to this, in the present article, the CALPHAD method is introduced. For all the calculations, temperature $(T)$ and total pressure $(P)$ are held to be constant.

\subsection{Border Line Method}

This method provides a stability diagram similar to that shown in Fig. 1. Only phase boundaries can be obtained. That is, only thick lines in Fig. 3 are drawn. For example, a phase boundary separating " $\mathrm{Al}_{2} \mathrm{O}_{3}$ " and " $(\mathrm{Ti}, \mathrm{Fe})_{3} \mathrm{O}_{5}$ " can be obtained by considering the following reaction:

$$
10 \underline{\mathrm{Al}}+3 \mathrm{Ti}_{3} \mathrm{O}_{5}(\mathrm{~s})=9 \underline{\mathrm{Ti}}+5 \mathrm{Al}_{2} \mathrm{O}_{3}(\mathrm{~s}) ; \quad K_{[3 \mathrm{a}]} \ldots \ldots .(3 \mathrm{a})
$$




$$
\begin{aligned}
\log K_{[3 \mathrm{a}]}= & 9\left(\log f_{\underline{\mathrm{Ti}}}+\log [\text { pct Ti }]\right)+5 \log a_{\mathrm{Al}_{2} \mathrm{O}_{3}} \\
& -10\left(\log f_{\underline{\mathrm{Al}}}+\log [\text { pct Al }]\right)-3 \log a_{\mathrm{Ti}_{3} \mathrm{O}_{5}}
\end{aligned}
$$

where $K_{[3 \mathrm{a}]}, a_{\mathrm{Al}_{2} \mathrm{O}_{3}}, a_{\mathrm{Ti}_{3} \mathrm{O}_{5}}, f_{\underline{\mathrm{Al}}}$, and $f_{\underline{\underline{\mathrm{Ti}}}}$ are equilibrium constant of the Reaction [3a], activity of $\mathrm{Al}_{2} \mathrm{O}_{3}$ with respect to pure solid $\mathrm{Al}_{2} \mathrm{O}_{3}$, activity of $\mathrm{Ti}_{3} \mathrm{O}_{5}$ with respect to pure solid $\mathrm{Ti}_{3} \mathrm{O}_{5}$, activity coefficient of $\underline{\mathrm{Al}}$, that of $\underline{\mathrm{Ti}}$ (with respect to $1 \mathrm{wt} \%$ standard state), respectively. In many investigations, $f_{\underline{i}}$ is described by using Wagner's interaction parameter formalism with first order interaction parameters, $e_{i}^{j}: 40$ )

$$
\begin{gathered}
\log f_{\underline{\mathrm{Al}}}=e_{\mathrm{Al}}^{\mathrm{Al}}[\text { pct } \mathrm{Al}]+e_{\mathrm{Al}}^{\mathrm{Ti}}[\text { pct Ti }]+e_{\mathrm{Al}}^{\mathrm{O}}[\text { pct O }]+\cdots \ldots \\
\log f_{\underline{\mathrm{Ti}}}=e_{\mathrm{Ti}}^{\mathrm{Al}}[\text { pct } \mathrm{Al}]+e_{\mathrm{Ti}}^{\mathrm{Ti}}[\text { pct Ti }]+e_{\mathrm{Ti}}^{\mathrm{O}}[\text { pct O }] \ldots .
\end{gathered}
$$

If necessary, second order interaction parameters may be used. Other model or formalism may be also used for the activity coefficient. The equilibrium constant $K_{[3 \mathrm{a}]}$ in the Eq. (3a), the interaction parameters in Eqs. (4) and (5) can be found in relevant literature. ${ }^{41)}$ Activities of the oxide components $\left(a_{\mathrm{Al}_{2} \mathrm{O}_{3}}\right.$ and $\left.a_{\mathrm{Ti}_{3} \mathrm{O}_{5}}\right)$ are set to predetermined values, since " $\mathrm{Al}_{2} \mathrm{O}_{3}$ " and " $(\mathrm{Ti}, \mathrm{Fe})_{3} \mathrm{O}_{5}$ " are in equilibrium each other. While " $\mathrm{Al}_{2} \mathrm{O}_{3}$ " is almost pure alumina $\left(a_{\mathrm{Al}_{2} \mathrm{O}_{3}}=1\right)$, $\mathrm{Ti}_{3} \mathrm{O}_{5}$ can dissolve $\mathrm{Fe}$, thereby expressed as " $(\mathrm{Ti}, \mathrm{Fe})_{3} \mathrm{O}_{5}$ " $\left(a_{\mathrm{Ti}_{3} \mathrm{O}_{5}}<1\right)$. Then, the Eq. (3b) is further changed as:

$$
\begin{aligned}
\log [\text { pct Ti }]= & \frac{10}{9} \log [\text { pct Al }]+\frac{10}{9}\left(\log f_{\underline{\mathrm{Al}}}-9 \log f_{\underline{\mathrm{Ti}}}\right) \\
& +\frac{1}{9}\left[\log K_{[3 \mathrm{a}]}-5 \log {a_{\mathrm{Al}_{2} \mathrm{O}_{3}}}+3 \log a_{\mathrm{Ti}_{3} \mathrm{O}_{5}}\right]
\end{aligned}
$$

where terms in the square bracket is approximately constant. If the [pct O] is known in advance, then the Eqs. (4) and (5) are functions of [pct Al] and [pct Ti]. The Eqs. (4) and (5) are then substituted in the Eq. (6) along with the $K_{[3 \mathrm{a}]}$, $a_{\mathrm{Al}_{2} \mathrm{O}_{3}}$, and $a_{\mathrm{Ti}_{3} \mathrm{O}_{5}}$ in order to obtain a set of [pct Al] and [pct Ti] at the [pct O]. It should be stressed that for each value of presumed [pct O], a corresponding set of [pct Al] and [pct Ti] are obtained. The obtained [pct Al] and [pct Ti] give the coordinate on the phase boundary (for example, the point $b$ in the Fig. 3).

Here, drawbacks of this method arise that the oxygen concentration is not known in advance, and the oxygen concentration is not a constant in general. In order to treat this situation, estimated oxygen concentration over whole diagram is used, ${ }^{12,13,26)}$ or unspecified value seemed to be used. $^{1,11,14,34,35)}$ Zhang et al. even presented different stability diagrams of the $\mathrm{Fe}-\mathrm{Al}-\mathrm{Mg}-\mathrm{O}$ system at different oxygen concentrations, although they suggested not to use this method. ${ }^{12)}$ This drawback arises indeed due to neglecting phase rule. At the boundary (such as at point $b$ ), number of equilibrium phases are three (liquid steel, $\mathrm{Al}_{2} \mathrm{O}_{3}$, and $\left.(\mathrm{Ti}, \mathrm{Fe})_{3} \mathrm{O}_{5}\right)$. According to the Gibbs phase rule $(f=c-p+$ 2), degree of freedom $f$ is $4-3+2(-2$ due to constant $T$ and $P)=1$, where the number of components $c$ is $4(\mathrm{Fe}$, $\mathrm{Al}, \mathrm{Ti}$, and $\mathrm{O}$ ). It means, only one concentration should be determined out of three $(\mathrm{Al}, \mathrm{Ti}$, and $\mathrm{O})$ in principle. Then, remaining two concentrations are automatically determined. However, when the Eq. (6) is solved with a presumed [pct $\mathrm{O}$ ], set of [pct Al] and [pct Ti] should be obtained automatically and simultaneously, which anyhow satisfy the Eq. (6).
Not all of these set are representing true equilibrium. Only using the Eq. (6), the equilibrium concentrations of $\mathrm{Al}, \mathrm{Ti}$, and $\mathrm{O}$ cannot be obtained for the three-phase equilibria (liquid steel $\left./ \mathrm{Al}_{2} \mathrm{O}_{3} /(\mathrm{Ti}, \mathrm{Fe})_{3} \mathrm{O}_{5}\right)$. Additional condition should be considered in order to construct a true stability diagram. Therefore, it is suggested not to use this border line method even to obtain the phase boundary.

\subsection{Iso-oxygen Contours Method}

In this method, a liquid steel of a given [pct O] assumed to be is in equilibrium with an oxide, over various [pct Al] and [pct Ti]. For example, in order to get an iso-oxygen contour (such as $\underline{b c}$ in the Fig. 3), the following reaction is considered:

$$
\begin{aligned}
& 2 \underline{\mathrm{Al}}+3 \underline{\mathrm{O}}=\mathrm{Al}_{2} \mathrm{O}_{3}(\mathrm{~s}) ; K_{[7 \mathrm{a}]} \\
& \log K_{[7 \mathrm{a}]}=\log a_{\mathrm{Al}_{2} \mathrm{O}_{3}}-2\left(\log f_{\underline{\mathrm{Al}}}+\log [\text { pct Al }]\right) \\
& -3\left(\log f_{\underline{\mathrm{O}}}+\log [\text { pct } \mathrm{O}]\right) \\
& \log f_{\underline{\mathrm{Al}}}=e_{\mathrm{Al}}^{\mathrm{Al}}[\text { pct } \mathrm{Al}]+e_{\mathrm{Al}}^{\mathrm{Ti}}[\text { pct } \mathrm{Ti}]+e_{\mathrm{Al}}^{\mathrm{O}}[\text { pct O }]+\cdots \\
& \log f_{\underline{\mathrm{O}}}=e_{\mathrm{O}}^{\mathrm{Al}}[\text { pct Al }]+e_{\mathrm{O}}^{\mathrm{Ti}}[\text { pct Ti }]+e_{\mathrm{O}}^{\mathrm{O}}[\text { pct O }]+\cdots \cdots
\end{aligned}
$$

where $K_{[7 \mathrm{a}]}$ and $f_{\mathrm{O}}$ are equilibrium constant of the Reaction [7a] and activity coefficient of $\mathrm{O}$, respectively.

Setting $[\mathrm{ppm} \mathrm{O}]=30$ for the line $b c$, substituting it in the Eqs. (4) and (8) results in the $f_{\underline{\mathrm{Al}}}$ and the $f_{\underline{\mathrm{O}}}$ as functions of [pct Al] and [pct Ti]. Further substitution of the Eqs. (4) and (8) in the Eq. (7b), along with the appropriate values of $K_{[7 \mathrm{a}]}$ and $a_{\mathrm{Al}_{2} \mathrm{O}_{3}}$ (usually assumed to be unity for pure solid alumina), yields a set of [pct Al] and [pct Ti]. Or [pct Al] is obtained by solving the Eq. (7b) at each [pct Ti]. This results in the line $b c$. This procedure is repeated at different [ppm O] as long as [pct Al], [pct Ti], and [ppm O] satisfy the Eq. (7b). As a result, a number of iso-[ppm O] lines of $\mathrm{Al}_{2} \mathrm{O}_{3}$ stable region are obtained as shown in the Fig. 3. Similar steps are repeated for other oxides such as "( $\mathrm{Ti}, \mathrm{Fe})_{3} \mathrm{O}_{5}$ " - pseudobrookite solid solution, " $(\mathrm{Ti}, \mathrm{Al})_{2} \mathrm{O}_{3}$ " ilmenite solid solution, and "liquid oxide", which consists of $\mathrm{Fe}_{t} \mathrm{O}-\mathrm{Al}_{2} \mathrm{O}_{3}-\mathrm{TiO}_{x}$, with oxidation reactions of corresponding oxide phases, similar to the Eq. (7a). For example, for the line $a b$, the following equilibrium is considered:

$$
\begin{aligned}
& 3 \underline{\mathrm{Ti}}+5 \underline{\mathrm{O}}=\mathrm{Ti}_{3} \mathrm{O}_{5}(\mathrm{~s}) ; K_{[9 \mathrm{a}]} \\
& \log K_{[9 \mathrm{a}]}=\log a_{\mathrm{Ti}_{3} \mathrm{O}_{5}}-3\left(\log f_{\underline{\mathrm{Ti}}}+\log [\mathrm{pct} \mathrm{Ti}]\right) \\
& -5\left(\log f_{\underline{\mathrm{O}}}+\log [\text { pct } \mathrm{O}]\right) \\
& \log f_{\underline{\mathrm{Ti}}}=e_{\mathrm{Ti}}^{\mathrm{Al}}[\text { pct } \mathrm{Al}]+e_{\mathrm{Ti}}^{\mathrm{Ti}}[\text { pct } \mathrm{Ti}]+e_{\mathrm{Ti}}^{\mathrm{O}}[\text { pct O }]+\cdots \\
& \log f_{\underline{\mathrm{O}}}=e_{\mathrm{O}}^{\mathrm{Al}}[\text { pct Al }]+e_{\mathrm{O}}^{\mathrm{Ti}}[\text { pct Ti }]+e_{\mathrm{O}}^{\mathrm{O}}[\text { pct O }]+\cdots
\end{aligned}
$$

At the point $b$, the line $b c$ for " $\mathrm{Al}_{2} \mathrm{O}_{3}$ " and the line $a b$ for " $(\mathrm{Ti}, \mathrm{Fe})_{3} \mathrm{O}_{5}$ " intersect each other. This point represents cosaturation of the liquid steel by " $\mathrm{Al}_{2} \mathrm{O}_{3}$ " and " $(\mathrm{Ti}, \mathrm{Fe})_{3} \mathrm{O}_{5}$ ". Connecting these points consists of the phase boundary which divides region of equilibrium oxide phases (thick lines in blue). 
This method is more reasonable than the "border line" method, because it explicitly considers the equilibrium oxygen concentration by the deoxidation reactions (Eqs. (7a) and (9a)). Zhang et al. pointed out this and recommended to use this method. ${ }^{12)}$

In this "iso-oxygen contours" method, it is important to know in advance 1) stable phase that is in equilibrium with the liquid steel, and 2) activity of each oxide component. In particular for the latter issue, it is not easy to get the activity values of oxide components in the liquid oxide, as the values vary with compositions of the liquid oxide.

\subsection{CALPHAD Method}

The iso-oxygen contours method is in principle correct, provided that all the thermodynamic information is accurately known. These include 1) stable phases which are in equilibrium with the liquid steel of given compositions and 2) activity of oxide component in the equilibrium oxide phase. In many cases, existence of a stable phase is assumed, and activity of the oxide component is set to appropriate constant value for simplicity. This approach is acceptable when the oxide phase is near stoichiometric phase such as $\mathrm{MgAl}_{2} \mathrm{O}_{4}$-spinel, calcium aluminates $\left(\mathrm{CaAl}_{2} \mathrm{O}_{4}, \mathrm{CaAl}_{4} \mathrm{O}_{7}\right.$, etc. $)$, or a solid solution of almost constant composition ( $(\mathrm{Ti}, \mathrm{Fe})_{3} \mathrm{O}_{5}$ pseudobrookite solid solution, $(\mathrm{Ti}, \mathrm{Al})_{2} \mathrm{O}_{3}$ ilmenite solid solution, etc.). However, if a liquid oxide is in equilibrium with a liquid steel, activity of components in the liquid oxide cannot be set to constant.

The CALPHAD method has been widely used in order to calculate multicomponent-multiphase equilibria and various phase diagram sections. Gibbs energy of each phase in a given system is formulated as a function of $T, P$, and concentration. Then, a thermodynamic equilibrium is obtained by minimizing Gibbs energy of the whole system (sum of Gibbs energies of all relevant phases in the system), subject to mass balance. Phase diagram is a result of thermodynamic equilibria, and it is plotted by the concept of Zero-Phase Fraction line. ${ }^{42)}$ As the oxide stability diagram is a projection of phase diagram sections, the CALPHAD method is easily applied to the construction of the oxide stability diagram.

The two issues raised in the iso-oxygen contours method are easily solved. First, stable phase in equilibrium with the liquid steel is automatically identified after minimizing the Gibbs energy of the whole system. This is because the presence of the equilibrium phase should give the minimum Gibbs energy. Second, although activity of component in oxide phase is not explicitly appeared during the calculation, it is inherently taken into account by the Gibbs energy equation of each phase. At a given equilibrium condition that is found by minimizing the Gibbs energy of the whole system, Gibbs energy of each phase (liquid steel and equilibrium oxide phase(s)) consists of partial Gibbs energies of constituting components, which are a function of activity of the components.

In a number of previous researches, the CALPHAD method was employed in order to construct oxide stability diagrams. In the present article, the CALPHAD method was also used to construct the oxide stability diagrams and the deoxidation curves. FactSage thermodynamic software was used $^{44,45)}$ along with FTmisc, FactPS, and FTOxid

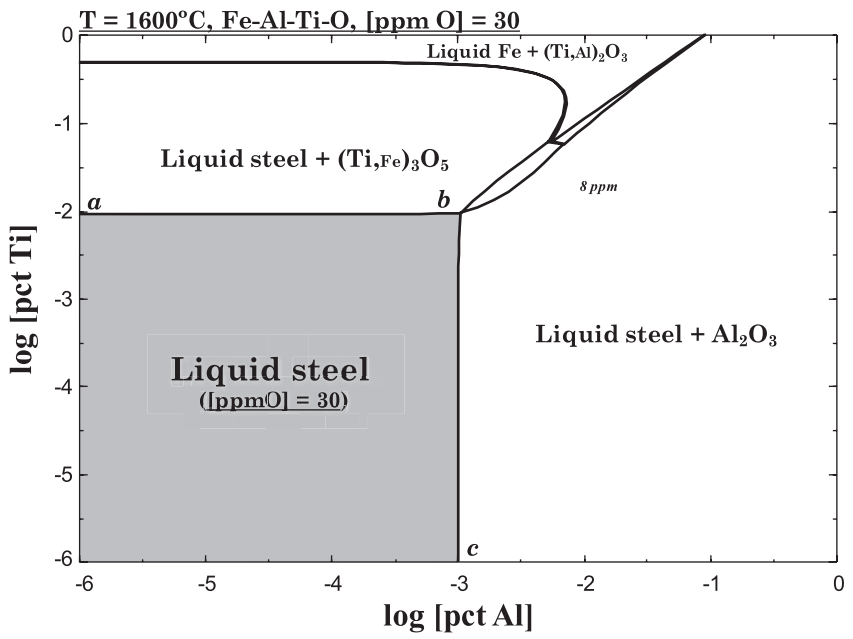

Fig. 6. An iso-oxygen phase diagram section of $30 \mathrm{ppm} O$ of the $\mathrm{Fe}-\mathrm{Al}-\mathrm{Ti}-\mathrm{O}$ system at $1600^{\circ} \mathrm{C}$. Shaded area is a single phase region of liquid steel containing $30 \mathrm{ppm} \mathrm{O.} \mathrm{'} a$ ', ' $b$ ', ' $c$ ' are identical to those in Fig. 3.

database to represent Gibbs energy of liquid steel, gas (rich in $\mathrm{CO}(\mathrm{g})$ ), and solid oxide phases, respectively. In the Fig. $3, \mathrm{Al}_{2} \mathrm{O}_{3}$-corundum, $(\mathrm{Ti}, \mathrm{Fe})_{3} \mathrm{O}_{5}$ pseudobrookite solid solution, $(\mathrm{Ti}, \mathrm{Al})_{2} \mathrm{O}_{3}$ ilmenite solid solution were considered. The present author's own database was used for the liquid oxide phase. ${ }^{23)}$

Figure 6 shows a calculated iso-[ppm O] phase diagram section of the $\mathrm{Fe}-\mathrm{Al}-\mathrm{Ti}-\mathrm{O}$ system at $1600^{\circ} \mathrm{C}$, [ppm O] = 30. A number of regions are distinguished by several lines. Among these lines, the line $a b c$ represents a limit of a single phase region of the liquid steel containing [ppm O] $=30$. The line $a b$ is a part of Zero-Phase Fraction (ZPF) line of $(\mathrm{Ti}, \mathrm{Fe})_{3} \mathrm{O}_{5}$ phase (above which the phase fraction of $(\mathrm{Ti}, \mathrm{Fe})_{3} \mathrm{O}_{5}$ is greater than zero, and below which the phase fraction of (Ti,Fe $)_{3} \mathrm{O}_{5}$ is zero), and the line $b c$ is a ZPF line of $\mathrm{Al}_{2} \mathrm{O}_{3}$. The lines $a b$ and $b c$ are a part of the oxide stability diagram shown in Fig. 3. The oxide stability diagram is then constructed as:

(1) Repeat calculations of iso-[ppm O] phase diagram sections at different [ppm O].

(2) Take each ZPF line of oxide phase in equilibrium with the liquid steel at each [ppm O] (such as $a b c$ ).

(3) Superimpose all these lines.

(4) Connect all co-saturation points (such as $b$ ). This results in the phase boundaries or border lines between two oxide phases.

Following these steps, the oxide stability diagram of the $\mathrm{Fe}-\mathrm{Al}-\mathrm{Ti}-\mathrm{O}$ system at $1600^{\circ} \mathrm{C}$ can be constructed (Fig. 3). The line $a b c$ in the Fig. 6 is indeed identical to that in Fig. 3.

In all of the above methods, it is obvious and important to have accurate and reliable thermodynamic data (equilibrium constant, activity coefficient, activity of oxide component, or thermodynamic database which consists of Gibbs energy model parameters) during the construction of the oxide stability diagrams. Without such accurate thermodynamic data, the constructed diagram may be in error.

\section{Rule of Phase Diagram Construction}

In order to give meaningful information, the oxide sta- 
bility diagram should obey rule of phase diagram. Each iso-oxygen section (such as Fig. 6) should be a true phase diagram that each point of the section represents one unique equilibrium state. Oxide stability diagram is the projection of several iso-oxygen phase diagram sections, therefore, its interpretation may look similar to liquidus projection, which is a projection of several iso-thermal phase diagram sections. As ZPF lines of several solid phases were taken in each iso-thermal section for the liquidus projection, $\mathrm{ZPF}$ lines oxide phases in equilibrium with the liquid steel were taken in each iso-oxygen section for the oxide stability diagram. It has been well understood how multicomponent iso-thermal phase diagram section is calculated, ${ }^{37,42}$ ) and how liquidus projection is constructed and utilized. ${ }^{37,43}$ Therefore, similar argument can be made in the construction of oxide stability diagram. In this section, construction rule of general phase diagram given by Pelton is introduced. ${ }^{37)}$ More detailed discussion is given in Pelton ${ }^{37)}$ and Hillert. ${ }^{38)}$

\subsection{Construction}

Construction of phase diagram should reflect thermodynamic equilibria, which are determined by state variables of a given system. If the system consists of $c$ components, there are $c+2$ thermodynamic potentials $\phi_{i}(i=1$ to $c+$ 2): $T, P, \mu_{1}, \mu_{2}, \ldots, \mu_{c}$, where $\mu_{i}$ is the chemical potential of the component $i$. For each potential, there is corresponding extensive variable $q_{i}$ :

$$
\phi_{i}=\left(\frac{\partial U}{\partial q_{i}}\right)_{q_{j(i \neq j)}}
$$

which are simply $S,-V, n_{1}, n_{2}, \ldots, n_{c}$, where $n_{i}$ is the number of moles of the component $i$. Here, $U, S$, and $V$ refer to the internal energy, entropy, and volume of the system, respectively. Each pair $\left(\phi_{i}-q_{i}\right)$ is called a conjugate pair. In order to construct true phase diagram (section), one and only one variable (either $\phi_{i}$ or $q_{i}$ ) from each of $c+2$ conjugate pairs should be chosen. Among $c$ extensive variables $\left(q_{i}\right.$ except for $S$ and $-V), k$ variables are then selected and are subjected to make $k-1$ ratios. These $k-1$ ratios along with the $c+$ $2-k$ selected potentials are the $c+1$ required variables. Two of these are chosen as axes variables and the $c-1$ others are held constant. ${ }^{37)}$

Corresponding pairs of potential and extensive variable in case of the $\mathrm{Fe}-\mathrm{Al}-\mathrm{Ti}-\mathrm{O}$ system are listed in Table 2. There are total $4+2$ conjugate pairs $(c=4)$. In order to

Table 2. Conjugate pairs of potentials $\left(\phi_{i}\right)$ and extensive variables $\left(q_{i}\right)$ of the $\mathrm{Fe}-\mathrm{Al}-\mathrm{Ti}-\mathrm{O}$ system.

\begin{tabular}{lccccccc}
\hline Potential & $\phi_{i}$ & $T$ & $P$ & $\mu_{\mathrm{Fe}}$ & $\mu_{\mathrm{Al}}$ & $\mu_{\mathrm{Ti}}$ & $\mu_{\mathrm{O}}$ \\
\hline $\begin{array}{l}\text { Extensive } \\
\text { variable } \\
\text { and ratio }\end{array}$ & $S$ & $-V$ & $n_{\mathrm{Fe}}$ & $n_{\mathrm{Al}}$ & $n_{\mathrm{Ti}}$ & $n_{\mathrm{O}}$ \\
\hline $\begin{array}{l}\text { Selected } \\
\text { variable }\end{array}$ & $T$ & $P$ & - & {$[$ pct Al] } & {$[$ pct Ti] } & {$[$ pct O] } \\
\hline $\begin{array}{l}\text { condition } \\
\text { constant constant }\end{array}$ & $\begin{array}{c}\text { set to } \\
\text { const }\end{array}$ & set to & & $X$-axis & $Y$-axis & $\begin{array}{c}\text { set to } \\
\text { constant }\end{array}$ \\
\hline
\end{tabular}

a) dependent variable by the relation: $\sum[$ pct $i]=100$

b) $[$ pet $i]=\mathrm{M}_{i} n_{i} / \sum \mathrm{M}_{j} n_{j}$ where $\mathrm{M}_{i}$ is a molecular weight of $i$, thus a transformation from $n_{i}$. calculate a phase diagram section in Fig. 6, 2 potentials $(T$, $P$ ) and 3 extensive variable ratios ([pct Al], [pct Ti], and [pct O]), total 5 were chosen $(4+1)$. Among the 5 potential/ratios, two ([pct Al], [pct Ti]) were selected as the axes variable. 3 others were set to constant: $[\mathrm{ppm} \mathrm{O}]=30, T=$ $1600^{\circ} \mathrm{C}, P=1$ bar. Therefore, shown in Fig. 6 is a true phase diagram that each point in the diagram gives unique equilibrium state.

Oxide stability diagram is then constructed by taking line $a b c$ in the Fig. 6, and similar lines (ZPF line of oxides) in other sections of different [ppm O], and by superimposing those lines. This is equivalent to say that the phase diagram sections are projected in [ppm O] direction. Therefore, $[\mathrm{ppm}$ $\mathrm{O}]$ is no more constant in the oxide stability diagram. This is sometimes overlooked during the construction of oxide stability diagrams in literature.

If more components are considered, then extensive variable ratio corresponding to those additional components should be set to constant, or it may also be used as an axis variable, while concentration of the component whose concentration was already used as an axis variable must be set to a constant instead. Otherwise, the calculated phase diagram section is no more giving unique equilibrium state. And interpretation of the constructed oxide stability diagram based on these phase diagram section becomes ambiguous. Use of various CALPHAD software automatically obeys the phase diagram rule. ${ }^{44-48)}$

\subsection{Interpretation}

Numbers given in the stability diagram (Fig. 3) represents oxygen concentration in the liquid steel. It should be stressed that the oxygen concentration is soluble, not total. It is evident in the Fig. 6. Oxygen concentration in the liquid steel in the shaded area including line $a b c$ is exactly $30 \mathrm{ppm}$. Oxygen concentration in the liquid steel outside this region is lower than $30 \mathrm{ppm}$, because of oxide formation.

One should read the line $b c$ in Fig. 3 that along the line $b c$, the liquid steel contains $30 \mathrm{ppm} \mathrm{O}$, corresponding [pct $\mathrm{Al}$ ] and [pct Ti] can be read from $x$ - and $y$ - axis, and the steel is about to precipitate $\mathrm{Al}_{2} \mathrm{O}_{3}$. The [pct Al] and [pct Ti] are all soluble concentrations. On the line $b c$ (given [pct Al] and [pct Ti]), if [ppm O] is higher than $30 \mathrm{ppm}$, then liquid steel does precipitate $\mathrm{Al}_{2} \mathrm{O}_{3}$ : [pct Al] and [ppm O] decrease. Then actual soluble concentrations of $\mathrm{Al}, \mathrm{Ti}$, and $\mathrm{O}$ cannot be read from the diagram. This is because this diagram does not provide how much the $\mathrm{Al}_{2} \mathrm{O}_{3}$ was precipitated. Therefore, the final composition of the liquid steel cannot be obtained from the initial condition once the oxide is formed. On the other hand, if [ppm O] is lower than $30 \mathrm{ppm}$, then $\mathrm{Al}, \mathrm{Ti}$, and $\mathrm{O}$ concentrations are all soluble, and $\mathrm{Al}_{2} \mathrm{O}_{3}$ is not stable. For other iso-oxygen lines, the interpretation is straightforward.

If there is additional component in the liquid steel, then its concentration is kept only when any oxide is not formed. Otherwise, concentration of the additional component would vary even though the component is not forming the oxide. This will be discussed in Sec. 4.4.

It can be generalized as "O concentration given to an iso-oxygen contour line is soluble concentration in the liquid steel. Concentrations of oxidizing components used for $x$ - and $y$-axes on the line are also soluble concentrations. Concentrations of other components are all soluble. Increas- 
ing $\mathrm{O}$ concentration from the given $\mathrm{O}$ concentration leads to formation of oxide as specified in the diagram, but soluble concentrations of $\mathrm{O}$ and the other components cannot be read anymore. Decreasing $\mathrm{O}$ concentration from the given O concentration keeps soluble concentrations of the other components, and the oxide phase is not stable."

\section{Some Considerations for Utilization of Oxide Stabil- ity Diagram}

\subsection{Extension to Lower Concentrations of Oxidizing Components}

Oxide stability diagrams available in literature have been constructed that concentration axes extend usually down to $10^{-3}-10^{-4}$ pct. This is usually considered as lower limit of concentration of the oxidizing components in liquid steels. Upper limit of the diagram usually goes to a few pct to a few tens of pct, depending on the composition of the steel. In this composition range, oxidizing components react with dissolve oxygen in order to form corresponding oxides. In case of $\mathrm{Al}$, typical oxide is $\mathrm{Al}_{2} \mathrm{O}_{3}$. Figure 4 shows a calculated deoxidation curve of the $\mathrm{Fe}-\mathrm{Al}-\mathrm{O}$, using the CALPHAD method as described in Sec. 2.3. ${ }^{8,44,45)} \mathrm{Al}_{2} \mathrm{O}_{3}$ is stable oxide phase in equilibrium with liquid steels when [pct Al] is higher than $\sim 0.00002$. In practice, $\mathrm{Al}$ concentration in liquid steel would not be lower than this. Figure 5 shows a deoxidation curve in the $\mathrm{Fe}-\mathrm{Ti}-\mathrm{O}$ system, using the same method. ${ }^{8,44,45)}$ When [pct Ti] is higher than $\sim 0.0006$, equilibrium oxide phase is either $(\mathrm{Ti}, \mathrm{Fe})_{3} \mathrm{O}_{5}$, or $\mathrm{Ti}_{2} \mathrm{O}_{3}$, depending on the [pct Ti]. Those are all solids at $1600^{\circ} \mathrm{C}$. On the other hand, at lower Ti content ( $<\sim 0.001$ pet.), a liquid oxide forms as an equilibrium oxide. This consists of not only $\mathrm{Ti}$ oxide but also Fe oxide.

In principle, the liquid oxide consisting of $\mathrm{Fe}$ oxide can form at lower content of the oxidizing components. Although a liquid steel generally contains oxidizing components such as $\mathrm{Al}, \mathrm{Si}, \mathrm{Ti}, \mathrm{Mn}$, etc. in order not to form the liquid $\mathrm{Fe}$ oxide, it may form under certain circumstances such as reoxidation. Forming the liquid oxide containing Fe oxide may be responsible for agglomeration of inclusions in liquid steel ${ }^{49)}$ or deposit growth at interface between refractory and liquid steel. ${ }^{50,51)}$ Lower limit of concentration of oxidizing components regarding the liquid oxide formation

Table 3. Critical content of liquid steel deoxidized by each oxidizing component $(M)$ in $\mathrm{Fe}-M-\mathrm{O}$ system at $1600^{\circ} \mathrm{C}$, where liquid steel, liquid oxide, and a solid oxide are in equilibrium. In case of $M=\mathrm{C}$, a gas phase rich in $\mathrm{CO}(\mathrm{g})$ is in equilibrium instead of a solid oxide. Data shown in this table was calculated using FactSage with FTmisc, FToxid, and FactPS databases. ${ }^{44,45)}$

\begin{tabular}{cccc}
\hline $\begin{array}{c}\text { Oxidizing } \\
\text { component } M\end{array}$ & {$[\text { pct } M]_{\mathrm{cr}}$} & {$[\text { pct }]_{\mathrm{cr}}$} & Oxide phases \\
\hline $\mathrm{Al}$ & $1.0471 \times 10^{-05}$ & $1.6627 \times 10^{-01}$ & Liquid oxide $/ \mathrm{FeAl}_{2} \mathrm{O}_{4}$ \\
$\mathrm{Si}$ & $5.8218 \times 10^{-03}$ & $5.9795 \times 10^{-02}$ & Liquid oxide $/ \mathrm{SiO}_{2}$ \\
$\mathrm{Mn}$ & $3.1662 \times 10^{-01}$ & $3.1662 \times 10^{-01}$ & Liquid oxide $/(\mathrm{Mn}, \mathrm{Fe}) \mathrm{O}$ \\
$\mathrm{Ti}$ & $8.2533 \times 10^{-04}$ & $1.2711 \times 10^{-02}$ & Liquid oxide $/(\mathrm{Ti}, \mathrm{Fe})_{3} \mathrm{O}_{5}$ \\
$\mathrm{Cr}$ & $5.0997 \times 10^{-02}$ & $2.0104 \times 10^{-01}$ & Liquid oxide $/ \mathrm{FeCr} \mathrm{O}_{4}$ \\
$\mathrm{C}$ & $7.6260 \times 10^{-03}$ & $2.1618 \times 10^{-01}$ & Liquid oxide $/ \mathrm{CO}(\mathrm{g})$ \\
\hline
\end{tabular}

depends on types of oxidizing components. Table 3 shows the critical concentrations of oxidizing components ([pct $\left.M]_{\mathrm{cr}}\right)$ and oxygen $\left([\text { pct } \mathrm{O}]_{\mathrm{cr}}\right)$ in liquid $\mathrm{Fe}-M-\mathrm{O}$, calculated by FactSage ${ }^{44,45)}$ and databases (Sec. 2.3). Equilibrium oxide phases including the liquid oxide are shown. When more than one oxidizing components present, the critical concentrations of oxidizing components increase and that of oxygen decrease. The Al-Ti complex deoxidation case is seen in the Fig. 3. As the formation of liquid oxide is thought to be important in steel cleanliness, ${ }^{49-51)}$ knowing the critical concentrations and conditions of forming the liquid oxide are thought to be useful. Therefore, it is proposed that axes of the oxide stability diagram to be extended to lower concentrations of oxidizing components, where the liquid oxide may exist.

\subsection{Stability Diagram to Read Reoxidation Path of Liquid Steel}

As mentioned in Sec. 3, an oxide stability diagram looks similar to a liquidus projection. The liquidus projection is a projection of several isothermal sections through temperature direction, while the oxide stability diagram is a projection of several iso-oxygen sections through oxygen concentration direction. As the liquidus projection can be used to track solidification path along the direction of decreasing temperature, the oxide stability diagram may be used to track reoxidation path along the direction of increasing oxygen concentration. An example may be seen in the Fig. 3. An open circle is located where [pct Al] and [pct Ti] are 0.01, each, and between iso-[ppm O] lines of $7 \mathrm{ppm}$ and $10 \mathrm{ppm}$. According to a thermodynamic calculation using the FactSage, the equilibrium oxygen concentration is $8 \mathrm{ppm}$. If the liquid steel of 0.01 pct Al- 0.01 pct. Ti contains oxygen less than $8 \mathrm{ppm}$, then the liquid steel is homogeneous without any oxide formed. When the steel is reoxidized by any reason, and oxygen concentration increases up to $8 \mathrm{ppm}$, then, it starts to precipitate $\mathrm{Al}_{2} \mathrm{O}_{3}$. When more reoxidation takes place, more $\mathrm{Al}_{2} \mathrm{O}_{3}$ forms. Since the formation of $\mathrm{Al}_{2} \mathrm{O}_{3}$ consumes $\mathrm{Al}$ and $\mathrm{O}$ simultaneously, soluble concentration of $\mathrm{Al}$ decreases ( $\mathrm{Ti}$ is not consumed, and $\mathrm{O}$ is supplied during the reoxidation). It continues until the soluble Al concentration reaches at the point $b$. At the point $b$, [pct Al], [pct Ti], and [ppm O] are approximately $0.001,0.01$, and 30, respectively. Further reoxidation causes co-precipitation of $\mathrm{Al}_{2} \mathrm{O}_{3}$ and $(\mathrm{Ti}, \mathrm{Fe})_{3} \mathrm{O}_{5}$, therefore, $\mathrm{Al}$ and $\mathrm{Ti}$ are consumed simultaneously. Reoxidation path moves to a direction of decreasing both [pct Al] and [pct Ti]. Fe also oxidizes slightly into the $(\mathrm{Ti}, \mathrm{Fe})_{3} \mathrm{O}_{5}$, but its extent may be ignored. $\mathrm{Al}$ and $\mathrm{Ti}$ are both oxidized until [ppm O] increases up to $51 \mathrm{ppm}$, where liquid oxide becomes stable (point $d$ ).

At this point, tracking reoxidation path is not always on the phase boundary between two phases (thick blue lines), contrary to the tracking solidification path in liquidus projection. Most simple answer is that mass balance is not kept during reoxidation (oxygen is supplied to the system), while the mass balance is kept during solidification. During the reoxidation, the liquid steel is oxidized, first by oxidizing component such as $\mathrm{Al}$ and $\mathrm{Ti}$ in this particular case, but eventually, $\mathrm{Fe}$ oxidizes. The liquid oxide eventually becomes rich in the Fe oxide. Since the Fe oxide is liquid at temperature of liquid steel, the tracking of the reoxida- 
tion should fall in the liquid oxide region in the stability diagram. Therefore, once the liquid oxide becomes stable at the point $d$, the reoxidation path would move on the phase boundary between liquid oxide and $\mathrm{Al}_{2} \mathrm{O}_{3}$ (de), but soon leaves the boundary in order to fall into liquid oxide region (equilibrium between liquid steel and liquid oxide). At extreme reoxidation, the path should direct to the origin of this diagram where [pct Al] and [pct Ti] decrease down to zero. When the path leaves from the phase boundary, and whether the path moves to a phase boundary between liquid oxide and $\mathrm{FeAl}_{2} \mathrm{O}_{4}$ or not, depend on initial composition of liquid steel.

In summary, the oxide stability diagram may be used to know 1) what is a first oxide phase for a liquid steel of given composition, 2) what intermediate phase would form during reoxidation before the liquid oxide forms, 3) that reoxidation path should direct to a direction of decreasing soluble concentrations of oxidizing components, 4) and that the reoxidation path eventually directed to the liquid oxide region and this is the only oxide phase at extreme reoxidation. In reality, for a medium reoxidation, the liquid oxide may co-exist with other oxide (e.g., $\mathrm{Al}_{2} \mathrm{O}_{3}$ ) in equilibrium with the liquid steel. ${ }^{47}$ )

\subsection{Deoxidation of Liquid Steel when More Than One Component are Oxidizing}

Although deoxidation of a liquid steel is well understood reaction, it would be interesting to read reaction path when more than one oxidizing components are added into liquid steel. In particular, it is interesting to see a case: when one oxidizing component is added in order to deoxidize the steel, while the other component is added to be alloyed in the steel although it is also oxidizing component. Ti-added ultra low $\mathrm{C}$ steel deoxidized by Al may corresponds to this case: $\mathrm{Al}$ is used as deoxidizer while $\mathrm{Ti}$ is used as an alloying component. It is important to know that how $\mathrm{Ti}$ can be added in the liquid steel without the oxidation.

After converter steelmaking, oxygen concentration in the liquid steel is high $(\sim 0.05$ pct.). $\mathrm{Al}$ and $\mathrm{Ti}$ are yet to be added. It may be said that $\mathrm{Al}$ and $\mathrm{Ti}$ concentrations of the steel would be near origin in Fig. 3, lower left corner (it should be noted that iso-oxygen lines near the origin has no meaning, as the oxygen concentration was said to be 0.05 pct.). Then, this steel is deoxidized by $\mathrm{Al}$ addition. Let us suppose that the steel is deoxidized until [ppm O] is lowered to $8 \mathrm{ppm}$, where [pct $\mathrm{Al}$ ] is $\sim 0.01$ pct. $\mathrm{Al}_{2} \mathrm{O}_{3}$ forms as an deoxidation product. During a $\mathrm{RH}$ process, ferro-Ti alloy is then added. This results in increasing [pct Ti] in the steel, and composition of the steel moves upward in the diagram. If the ferro Ti alloy is added to make [pct Ti] $\sim 0.01$ pct., then composition of the steel eventually reach the open circle. Change of the composition is shown by a dashed arrow. During this step, Ti will not be oxidized because the stable oxide phase is still $\mathrm{Al}_{2} \mathrm{O}_{3}$, provided that local enrichment of Ti is neglected. This is shown in Fig. 7, an iso-oxygen phase diagram section at $8 \mathrm{ppm}$ oxygen. Even at higher Ti concentration (i.e., [pct Ti] $=\sim 1$ ) by adding more ferro $\mathrm{Ti}$ alloy or local enrichment of $\mathrm{Ti}$ around the ferro $\mathrm{Ti}$ alloy (at the top of this diagram where $(\mathrm{Ti}, \mathrm{Al})_{2} \mathrm{O}_{3}$ is stable oxide phase), Ti would not be oxidized. This is because $[\mathrm{ppm} \mathrm{O}$ ] after the $\mathrm{Al}$ deoxidation is around $8 \mathrm{ppm}$,

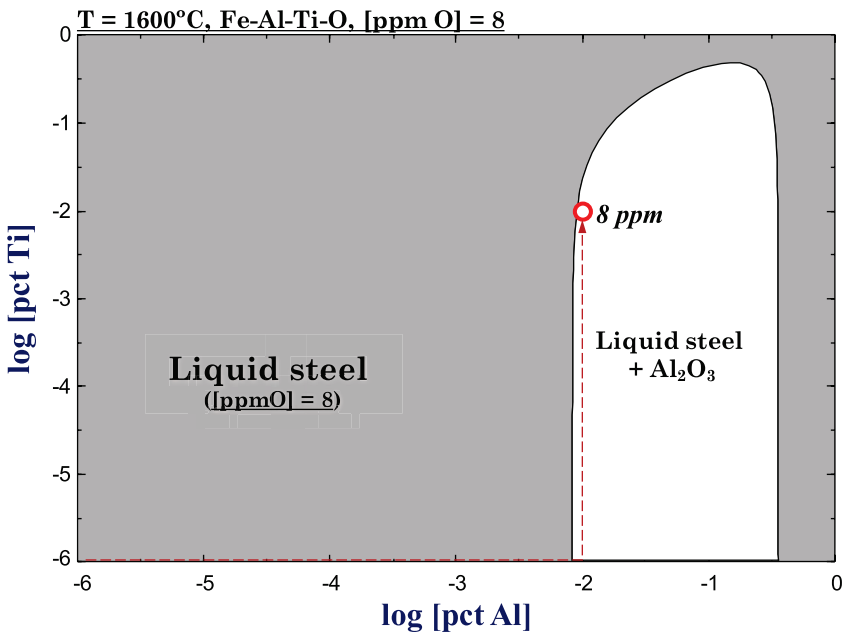

Fig. 7. An iso-oxygen phase diagram section of $8 \mathrm{ppm} \mathrm{O}$ of the $\mathrm{Fe}-\mathrm{Al}-\mathrm{Ti}-\mathrm{O}$ system at $1600^{\circ} \mathrm{C}$. Shaded area is a single phase region of liquid steel containing $8 \mathrm{ppm} \mathrm{O}$. A dashed arrow and an open circle are the same as those in Fig. 3. (Online version in color.)

which is lower than equilibrium [ppm O] in the $(\mathrm{Ti}, \mathrm{Al})_{2} \mathrm{O}_{3}$ region. According to the Fig. 7, only liquid steel of 8 ppm $\mathrm{O}$ is stable phase, with no Ti containing oxide formation.

On the other hand, if the Al deoxidation was done so as for [ppm O] to be $\sim 30 \mathrm{ppm}$ (near point $c$ ) in the Fig. 3 , followed by ferro Ti addition, then the Ti would not be oxidized until [pct Ti] increases up to $\sim 0.01$ (near point $b$ ). This can be read from Fig. 6. However, further addition of ferro $\mathrm{Ti}$ or local enrichment of $\mathrm{Ti}$ then causes oxidation of $\mathrm{Ti}$ by forming $(\mathrm{Ti}, \mathrm{Fe})_{3} \mathrm{O}_{5}$ (or $(\mathrm{Ti}, \mathrm{Al})_{2} \mathrm{O}_{3}$ depending on Ti content). This is due to facts that 1) stable oxide is Ti containing oxide, and 2) equilibrium [ppm O] in the liquid steel becomes lower than $30 \mathrm{ppm}$ which was obtained after the $\mathrm{Al}$ deoxidation. When both conditions are satisfied, Ti oxidation occurs, and this causes loss of Ti during ferro $\mathrm{Ti}$ addition.

These two examples show that deoxidation product can be read from the oxide stability diagram, by tracking not only concentration of deoxidizing components, but also by tracking concentration of oxygen.

\subsection{Oxide Stability Diagram of Liquid Steel Contain- ing $\mathbf{C}$}

Most liquid steel contains $\mathrm{C}$, except for ultra low $\mathrm{C}$ steel which contains less than a few tens of ppm of C. Since C also strongly reacts with $\mathrm{O}$ and forms gas phase rich in $\mathrm{CO}(\mathrm{g})$ :

$$
\begin{aligned}
& \underline{\mathrm{C}}+\underline{\mathrm{O}}=\mathrm{CO}(\mathrm{g}) ; K_{[11 \mathrm{a}]} \\
& \log K_{[11 \mathrm{a}]}=\log P_{\mathrm{CO}} / P^{\circ}-\left(\log f_{\mathrm{C}}+\log [\text { pct C }]\right) \\
& -\left(\log f_{\underline{\mathrm{O}}}+\log [\mathrm{pct} \mathrm{O}]\right)
\end{aligned}
$$

where $P_{\mathrm{CO}}$ and $P^{\circ}$ are partial pressure of $\mathrm{CO}$ and a pressure of standard state, respectively, oxide stability diagram would be altered by the formation of gas phase. Also, activity coefficient of oxidizing component in the liquid steel is varied by $\mathrm{C}$. Therefore, it should be considered during the construction of oxide stability diagram for practical steel 
grade.

Figure 8 shows a deoxidation curve of $\mathrm{Fe}-\mathrm{C}-\mathrm{O}$ system at $1600^{\circ} \mathrm{C}^{44,45,52)}$ When $\mathrm{C}$ concentration is low, liquid oxide composed of $\mathrm{Fe}$ oxide is in equilibrium with the liquid steel. When $\mathrm{C}$ concentration is higher, then gas phase forms. Now, it becomes interesting how $\mathrm{C}$ affects an oxide stability diagram.

Let us consider the $\mathrm{Fe}-\mathrm{Al}-\mathrm{Ti}-\mathrm{O}$ system with $\mathrm{C}$. Since one additional component is considered, according to the discussion in Sec. 3.1, concentration of $\mathrm{C}$ need to be set to constant for the construction of the oxide stability diagram.

An iso-oxygen phase diagram section similar to Fig. 6 (i.e., $[\mathrm{ppm} \mathrm{O}]=30$ ) was calculated when the liquid steel contains 0.1 pct. C, and it is shown in Fig. 9. According to Fig. 8, the liquid steel containing 0.1 pct. $\mathrm{C}$ and $30 \mathrm{ppm}$ $\mathrm{O}$ does not form gas phase. Having $\mathrm{Al}$ and $\mathrm{Ti}$ in the steel would not generate the gas phase either. Therefore, the isooxygen phase diagram section looks very similar to Fig. 6. Only minor change may be observed, and this is due to the effect of 0.1 pct. $\mathrm{C}$ on the activity coefficient of other

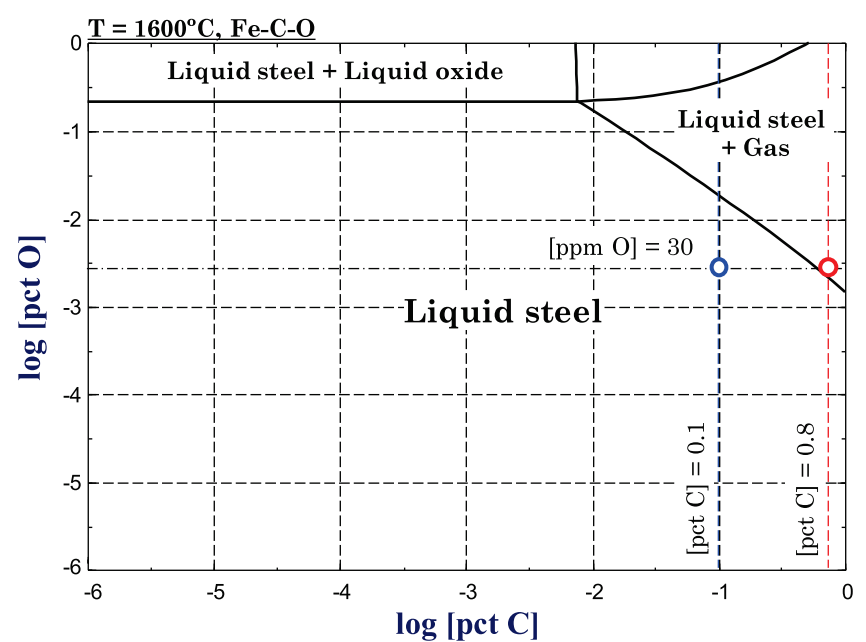

Fig. 8. A deoxidation curve of the $\mathrm{Fe}-\mathrm{C}-\mathrm{O}$ system at $1600^{\circ} \mathrm{C}$. Liquid oxide is in equilibrium with liquid steel when [pct C] $<7.6260 \times 10^{-03}$. (Online version in color.)

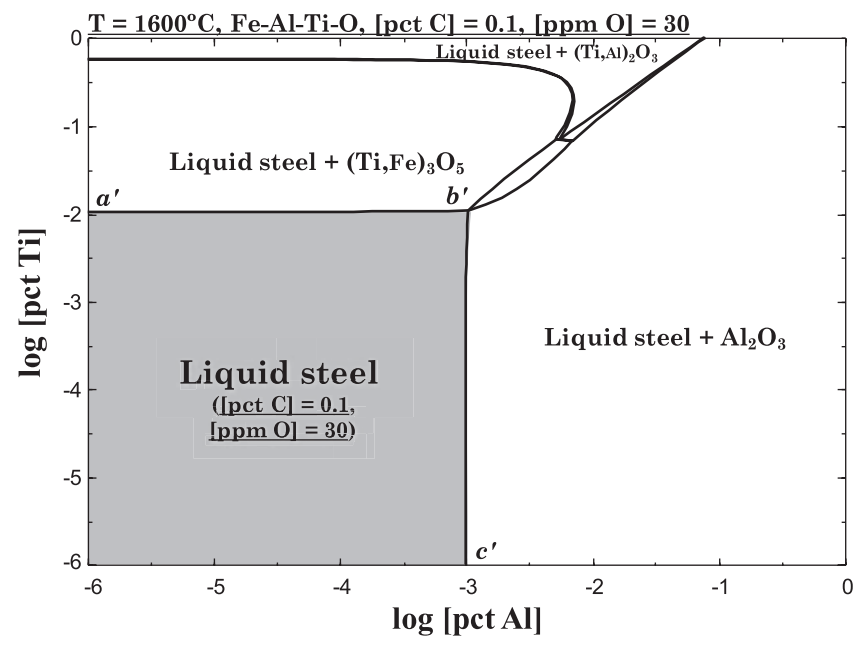

Fig. 9. An iso-oxygen phase diagram section of $30 \mathrm{ppm} \mathrm{O}$ of the $\mathrm{Fe}-\mathrm{C}-\mathrm{Al}-\mathrm{Ti}-\mathrm{O}$ system at $1600^{\circ} \mathrm{C}$ when [pct $\mathrm{C}$ ] $=0.1$. Shaded area is a single phase region of liquid steel containing $30 \mathrm{ppm} \mathrm{O}$. solutes ( $\mathrm{Al}, \mathrm{Ti}$, and $\mathrm{O})$. Limit of the liquid steel surrounded by $a^{\prime} b^{\prime} c$ ', whose [ppm O] is kept to be $30 \mathrm{ppm}$, can be used to construct oxide stability diagram of Fe-0.1C-Al-Ti-O system. The oxide stability diagram of the Fe-0.1C-Al-Ti-O system is shown in Fig. 10.

On the other hand, when liquid steel contains higher $\mathrm{C}$ or $\mathrm{O}$ concentration, a gas phase would form. For example, at the same oxygen content ( $30 \mathrm{ppm})$, a liquid steel containing 0.8 pct. $\mathrm{C}$ does generate gas phase, as can be seen in Fig. 8. An iso-oxygen phase diagram section ( $30 \mathrm{ppm} \mathrm{O}$ ) of 0.8 pct. C containing steel with $\mathrm{Al}$ and $\mathrm{Ti}$ was calculated and it is shown in Fig. 11. As seen in the figure, gas phase was generated at low $\mathrm{Al}$ and $\mathrm{Ti}$ concentrations. In this section, there is no region where the liquid steel is the only stable phase. It means, [ppm O] (soluble concentration of oxygen) in the liquid steel cannot be kept to be $30 \mathrm{ppm}$. Therefore, it is not possible to extract lines such as $a b c$ (Fig. 6) or $a^{\prime} b^{\prime} c^{\prime}$ (Fig. 9). This section is not used in constructing an oxide

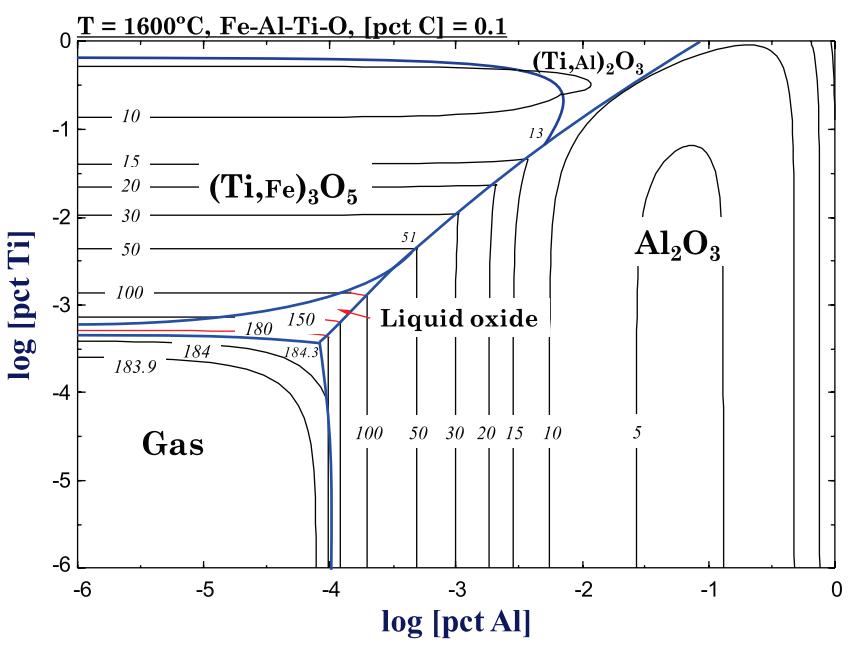

Fig. 10. Oxide stability diagram of the $\mathrm{Fe}-\mathrm{C}-\mathrm{Al}-\mathrm{Ti}-\mathrm{O}$ system at $1600^{\circ} \mathrm{C}$ when [pct $\mathrm{C}$ ] $=0.1$. A gas phase forms when [pct Al] and [pct Ti] are low, and liquid oxide region is reduced. (Online version in color.)

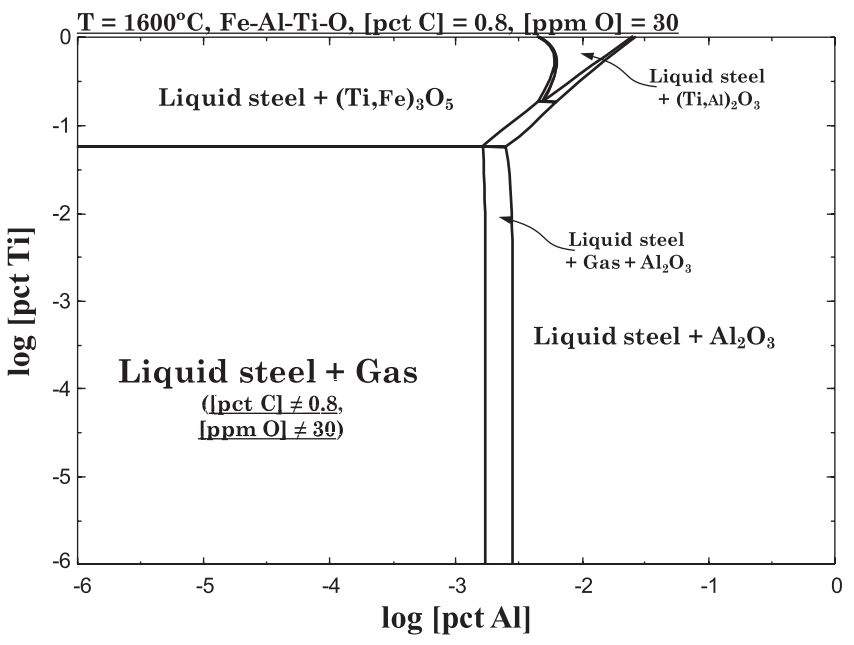

Fig. 11. An iso-oxygen phase diagram section of $30 \mathrm{ppm} \mathrm{O}$ of the $\mathrm{Fe}-\mathrm{C}-\mathrm{Al}-\mathrm{Ti}-\mathrm{O}$ system at $1600^{\circ} \mathrm{C}$ when [pct $\left.\mathrm{C}\right]=0.8$ There is no region of liquid steel which keeps [ppm O] = 30 as well as [pet $\mathrm{C}]=0.8$. A gas phase rich in $\mathrm{CO}(\mathrm{g})$ forms when [pct Al] and [pct Ti] are low. 


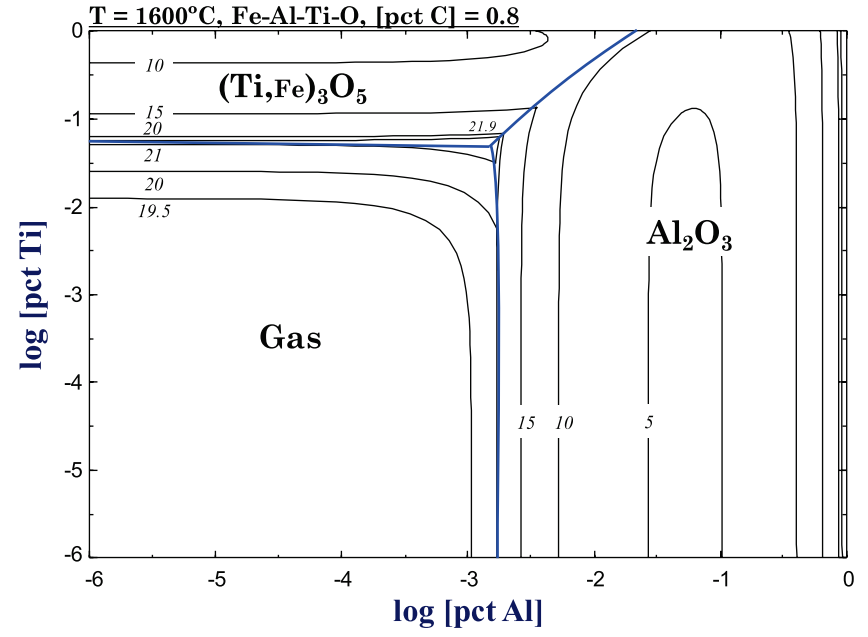

Fig. 12. Oxide stability diagram of the $\mathrm{Fe}-\mathrm{C}-\mathrm{Al}-\mathrm{Ti}-\mathrm{O}$ system at $1600^{\circ} \mathrm{C}$ when [pct $\left.\mathrm{C}\right]=0.8$. A gas phase forms when [pct $\mathrm{Al}]$ and [pct Ti] are low, and liquid oxide region is no more appeared. (Online version in color.)

stability diagram.

By collecting the limit of liquid steel phase containing $\mathrm{C}$ at various iso-oxygen concentration, an oxide stability diagram of $\mathrm{Fe}-0.8$ pct. $\mathrm{C}-\mathrm{Al}-\mathrm{Si}-\mathrm{O}$ was constructed and is shown in Fig. 12. When the Figs. 10 and 12 are compared with Fig. 3, significant changes are seen. First, stable region of gas phase appears at lower $\mathrm{Al}$ and $\mathrm{Ti}$ concentrations. It looks that stable region of the gas phase replaces that of the liquid oxide, which was stable at lower $\mathrm{Al}$ and $\mathrm{Ti}$ concentrations when [pct C] was zero. The higher C concentration is, the wider the stable region of gas phase is. Second, iso-oxygen contours in the region of the gas phase do not vary noticeably compared to that in the other oxide regions. Indeed, the oxygen concentration in the liquid steel that is in equilibrium with the gas phase is almost constant (varies within a few mass ppm). This is due to the equilibrium of the Reaction [11a] under the condition of constant $\mathrm{C}$ concentration and almost fixed $P_{\mathrm{CO}}$. Third, increasing $\mathrm{C}$ concentration affects activity coefficient of solutes (Al, Ti, and $\mathrm{O}$ ). This changes the position of iso-oxygen contours as well as position of stable oxide regions.

By examining the above, it is recommended that presence of $\mathrm{C}$ should be considered when an oxide stability diagram is constructed for $\mathrm{C}$ containing liquid steel.

It is finally stressed that the $\mathrm{C}$ concentration set to constant (0.1 in Fig. 10 and 0.8 in Fig. 12) are not kept to the specified value on the iso-oxygen contours in "Gas" region, due to the consumption of $\mathrm{C}$.

\section{Concluding Remarks}

Oxide stability diagram has been used in order to give information about stable oxide inclusion in equilibrium with liquid steel. Although it is a useful tool to understand inclusion evolution, its construction and interpretation have been sometimes unclear. Since the diagram is a projection of several iso-oxygen phase diagram sections, it should be constructed based on well-developed phase diagram rule. In this article, three methods to construct oxide stability diagram were reviewed. A CALPHAD method is proposed to be useful because:

(1) it naturally takes into account stable oxide phases which were found by minimizing Gibbs energy of the whole system,

(2) change of activity and activity coefficient of oxide components is taken into account,

(3) lines of iso-oxygen contours are efficiently calculated by Zero-Phase Fraction line concept.

Rule of phase diagram construction was introduced. According to the rule, two concentration variables are used as axes variables, and concentrations of all other components (except for Fe) are held constant, as well as $T$ and $P$, in order to calculate iso-oxygen phase diagram sections. By superimposing phase diagram sections of various iso-[ppm $\mathrm{O}]$, the oxide stability diagram is constructed. Concentrations shown in the diagram are all soluble (dissolved) concentrations.

The diagram can be used to track deoxidation/reoxidation path. When two oxidizing components are added in liquid steel, the diagram can be used to know what kind of oxide phase forms (as inclusion), and whether the other oxidizing component is oxidized or not. When oxygen is supplied to the liquid steel, the diagram can be used to follow what kind of oxide phase forms. It is evident that a liquid oxide rich in Fe oxide should form when reoxidation occurs significantly. This results in directing the reoxidation path to fall into a liquid oxide region in the oxide stability diagram. It is also proposed that the oxide stability diagram be constructed to include the liquid oxide rich in Fe-oxide. This requires axes of the diagram to be extended to lower concentration of oxidizing components.

Presence of $\mathrm{C}$ in a liquid steel should be considered. At high concentration of $\mathrm{C}$ or $\mathrm{O}$, a gas phase forms which is rich in $\mathrm{CO}(\mathrm{g})$. This affects stable oxide phases appeared in the oxide stability diagram. Also, at high $\mathrm{C}$ concentration, activity coefficient of components in the liquid steel is varied, which influences the shape of oxide stability diagram. This was shown by a number of oxide stability diagrams of $\mathrm{Al}-\mathrm{Ti}$ added liquid steel with different $\mathrm{C}$ concentration, as an example.

\section{REFERENCES}

1) E. T. Turkdogan: Physical Chemistry of High Temperature Technology, Academic Press, New York, (1980), 382.

2) E. Schürmann and N. Bannerberg: Arch. Eisenhüttenwes., 55 (1984), 455.

3) H. Gaye: Casting volume, The Making, Shaping and Treating of Steel, 11th ed., AISE Steel Foundation, Pittsburgh, PA, (2003), 8.

4) Y.-B. Kang and H.-G. Lee: ISIJ Int., 44 (2004), 1006.

5) H. Itoh, M. Hino and S. Ban-Ya: Metall. Mater. Trans. B, 28B (1997), 953.

6) J. D. Seo and S. H. Kim: Steel Res., 71 (2000), 101.

7) W.-G. Seo, W.-H. Han, J.-S. Kim and J.-J. Pak: ISIJ Int., 43 (2003), 201.

8) I.-H. Jung, S. A. Decterov and A. D. Pelton: ISIJ Int., 44 (2004), 527.

9) M. Jiang, X. Wang, B. Chen and W. Wang: ISIJ Int., 48 (2008), 885.

10) J. H. Park and H. Todoroki: ISIJ Int., 50 (2010), 1333.

11) G. Jing, C. Shu-Sen and C. Zi-Jian: ISIJ Int., 53 (2013), 2142.

12) L. Zhang, Y. Ren, H. Duan, W. Yang and L. Sun: Metall. Mater. Trans. B, 46B (2015), 1809.

13) M. Jiang, X. Wang, B. Chen and W. Wang: ISIJ Int., 50 (2010), 95.

14) T. Fujisawa and H. Sakao: Proc. Japan-Canada Seminar on Secondary Steelmaking, ISIJ, Tokyo, (1985), J-4-1.

15) H. Ohta and H. Suito: Metall. Mater. Trans. B, 28B (1997), 1131

16) I.-H. Jung, S. A. Decterov and A. D. Pelton: ISIJ Int., 44 (2004), 527.

17) F. Ruby-Meyer, J. Lehmann and H. Gaye: Scand. J. Metall., 29 (2000), 206.

18) H. Gaye: The Making, Shaping and Treating of Steel: Casting vol- 
ume, 11th Ed., AISE Steel Foundation, Pittsburgh, PA, (2003), 10.

19) H. Matsuura, C. Wang, G. Wen and S. Sridhar: ISIJ Int., 47 (2007), 1265

20) W.-Y. Kim, J.-O. Jo, C.-O. Lee, D.-S. Kim and J.-J. Pak: ISIJ Int., 48 (2008), 17.

21) I.-H. Jung, G. Eriksson, P. Wu and A. D. Pelton: ISIJ Int., 49 (2009), 1290.

22) M.-A. van Ende, M. Guo, R. Dekkers, M. Burty, J. V. Dyck, P. T. Jones, B. Blanpain and P. Wollants: ISIJ Int., 49 (2009), 1133.

23) Y.-B. Kang and J.-H. Lee: ISIJ Int., 57 (2017), 1665

24) Y.-B. Kang and J.-H. Lee: ISIJ Int., 57 (2017), 2269.

25) M.-K. Paek, K.-H. Do, Y.-B. Kang, I.-H. Jung and J.-J. Pak: Metall. Mater. Trans. B, 47B (2016), 2837.

26) Y. Kang, F. Li, K. Morita and D. Sichen: Steel Res. Int., 77 (2006), 785.

27) S.-K. Jo, S.-H. Kim and B. Song: Metall. Mater. Trans. B, 33 (2002), 703.

28) H. Ono, K. Nakajima, T. Ibuta and T. Usui: ISIJ Int., 50 (2010), 1955

29) Y. Ren, L. Zhang, W. Yang and H. Duan: Metall. Mater. Trans. B, 45B (2014), 2057.

30) T. Fujisawa and H. Sakao: Tetsu-to-Hagané, 63 (1977), 1494

31) E. T. Turkdogan and R. J. Fruehan: The Making, Shaping and Treating of Steel: Steelmaking and Refining Volume. 11th Ed., AISI Steel Foundation, Pittsuburgh, PA, (1998), 178.

32) H. Gaye: Casting volume, The Making, Shaping and Treating of Steel, 11 th ed., AISE Steel Foundation, Pittsburgh, PA, (2003), 9.

33) H. Todoroki and K. Mizuno: ISS Trans., 30 (2003), 60.

34) H. Todoroki and K. Mizuno: ISIJ Int., 44 (2004), 1350.

35) K. Sakata: ISIJ Int., 46 (2006), 1795.

36) J.-H. Shin and J.-H. Park: ISIJ Int., 58 (2018), 88.

37) A. D. Pelton: Phase Transformations in Materials, ed. by G. Kostorz,
Wiley-VCH Verlag GmbH, Weinheim, (2001), 56.

38) M. Hillert: J. Phase Equil., 18 (1997), 249.

39) I.-H. Jung: Calphad, 34 (2010), 332.

40) C. Wagner: Thermodynamics of Alloys, Addison-Wesley Press, Cambridge, MA, (1952), 47.

41) Steelmaking Data Source Book, Gordon \& Breach Science Publishers Ltd., Amsterdam, (1988), 1.

42) H. Gupta, J. E. Morral and H. Nowotny: Scr. Metall., 20 (1986), 889.

43) H.-G. Lee: Materials Thermodynamics with Emphasis on Chemical Approach, World Scientific, Singapore, (2012), 335.

44) C. W. Bale, E. Bélisle, P. Chartrand, S. A. Decterov, G. Eriksson, K. Hack, I.-H. Jung, Y.-B. Kang, J. Melançon, A. D. Pelton, C. Robelin and S. Petersen: Calphad, 33 (2009), 295.

45) C. W. Bale, E. Bélisle, P. Chartrand, S. A. Decterov, G. Eriksson, A. E. Gheribi, K. Hack, I.-H. Jung, Y.-B. Kang, J. Melançon, A. D. Pelton, S. Petersen, C. Robelin, J. Sangster, P. Spencer and M.-A. van Ende: Calphad, 54 (2016), 35.

46) J.-O. Andersson, T. Helander, L. Höglund, P. Shi and B. Sundman: Calphad, 26 (2002), 273.

47) R. H. Davies, A. T. Dinsdale, J. A. Gisby, J. A. J. Robinson and S. M. Martin: Calphad, 26 (2002), 229.

48) W. Cao, S.-L. Chen, F. Zhang, K. Wu, Y. Yang, Y. A. Chang, R. Schmid-Fetzer and W. A. Oates: Calphad, 33 (2009), 328.

49) T. Mizoguchi, Y. Ueshima, M. Sugiyama and K. Mizukami: ISIJ Int., 53 (2013), 639.

50) J.-H. Lee, S.-K. Kim, M.-H. Kang and Y.-B. Kang: Proc. 9th European Continuous Casting Conf. (ECCC), ASMET, Leoben, (2017), 565.

51) J.-H. Lee, M.-H. Kang, S.-K. Kim and Y.-B Kang: ISIJ Int., 58 (2018), 1257.

52) I.-H. Jung: ISIJ Int., 49 (2009), 1272 